\title{
WILEY
}

\section{Journal of Economics}

Den senaste bankreformen i Förenta Staterna

Author(s): D. D.

Source: Ekonomisk Tidskrift, Årg. 10, häft 9 (1908), pp. 327-331

Published by: Wiley on behalf of The Scandinavian Journal of Economics

Stable URL: http://www.jstor.org/stable/3437175

Accessed: 09-06-2016 05:59 UTC

Your use of the JSTOR archive indicates your acceptance of the Terms \& Conditions of Use, available at

http://about.jstor.org/terms

JSTOR is a not-for-profit service that helps scholars, researchers, and students discover, use, and build upon a wide range of content in a trusted digital archive. We use information technology and tools to increase productivity and facilitate new forms of scholarship. For more information about JSTOR, please contact support@jstor.org.

Wiley, The Scandinavian Journal of Economics are collaborating with JSTOR to digitize, preserve and extend access to Ekonomisk Tidskrift 


\section{Den senaste bankreformen i Förenta Staterna.}

Den sedan länge ifrågasatta bankreformen i Förenta Staterna har nyligen genom en lag af den 30 maj detta ăr ledt till ett positivt resultat. Denna lag afser dock ej att vara en allsidig och definitiv lösning af det krăngliga problemet. Den åsyftar sålunda först och främst blott att afhjälpa den brist på elasticitet, som städse vidlådit den amerikanska sedelutgifningen. Denna lags gällande kraft är vidare begränsad i tiden till den 30 juni 19I4. Slutligen bestämmer lagen, att det skall tillsättas en kommitté med uppdrag att, så fort ske kan, afge utlåtande om hvilka ändringar äro nödvändiga eller önskvärda med hänsyn till Förenta Staternas myntoch bankväsende, och för utförande af detta uppdrag äger kommittén bland annat besöka främmande länder för att studera dessas bankväsende. Kommittén är tillsatt, och en del af kommitténs ledamöter befinna sig för närvarande $\mathrm{i}$ Europa för studiet af några länders bankväsende och bland dessa äfven vårt.

Den nya lagen lämnar i det hela nu gällande bestämmelser rörande sedelutgifningen oförändrade, men tillfogar nya stadganden, afseende att tilldela de sedelutgifvande bankerna en extra sedelutgifningsrätt, så att de kunna tillgodose de behof af ökad sedelutgifning, som vid vissa tider eller tillfällen göra sig gällande.

Enligt hittills gällande lagstiftning äger nationalbank rätt att utge sedlar mot deponerande af unionsobligationer $i$ unionskassan såsom säkerhet. Det belopp af sedlar, som sålunda får utges, får ej öfverstiga vare sig marknadsvärdet eller det nominella värdet af de deponerade obligationerna och ej heller öfverstiga beloppet af bankens inbetalta aktiekapital. Hvarje nationalbank har dessutom skyldighet att i unionskassan deponera ett belopp i lagligt gällande mynt, motsvarande 5 procent af bankens utelöpande sedlar. Unionen inlöser bankernas sedlar, och för detta ändamål användas i främsta rummet vederbörande banks kassadepositioner och därefter de af banken deponerade unionsobligationerna. För de unionens fordringar på grund af inlösta banksedlar, som ej betäckas af nämnda tillgångar, äger unionen förmånsrätt $\mathrm{i}$ bankens öfriga tillgångar. 
Den nya sedelutgifningsrätt, som 1908 års lag skapat, făr grundas på andra värdepapper än unionsobligationer. ${ }^{1}$ För vissa fall godkännas ej andra värdepapper än sådana, som utgifvits af någon stat eller kommun inom Förenta Staterna och uppfylla vissa villkor. ${ }^{2}$ Under viss förutsättning kunna äfven andra slags värdepapper accepteras såsom grundval för den nya sedelutgifningen. Men för hvarje fall gäller, att det tillkommer vederbörande unionsmyndigheter att pröfva, om och till hvilket värde dylika värdepapper skola accepteras. Och äfven sedan en gång dylikt värdepapper emottagits săsom grundval för sedelutgifning, äger vederbörande myndighet föreskrifva, att säkerheten skall ökas eller att deponeradt värdepapper skall ersättas med annat.

Vidare är den nya sedelutgifningsrätten ej så ovillkorlig som den redan förut existerande. När nationalbank gör framställning om dylik extra sedelutgifning, har finansministern att pröfva, om förhăllandena inom den ort, där banken är belägen, kräfver ökad sedelutgifning, och, om detta befinnes vara fallet, huru stor ökning som behöfves. Begäran om dylik extra sedelutgifning kan sålunda afslås.

Ett annat villkor för att nationalbank skall kunna tilldelas dylik sedelutgifningsrätt är, att den till viss grad begagnat sin ordinarie rätt; dess på unionsobligationer grundade sedelutgifning skall uppgå till minst 40 procent af aktiekapitalet. Ett ytterligare villkor för att komma i åtnjutande af denna sedelutgifningsrätt är, att banken har en reservfond af minst 20 procent.

För öfrigt är denna nya sedelutgifningsrätt underkastad följande begränsningar. Den făr aldrig öfverstiga vissa procent af de deponerade värdepapperens värde. Detta procenttal är i allmänhet bestämdt till 75 procent, men i afseende å statens och kommunens obligationer till 90 procent. Vidare är det stadgadt, att summan af en banks ordinarie och extra ordinarie sedelutgifning ej făr öfverstiga summan af bankens kapital och reservfond. Slutligen făr den sammanlagda extraordinarie sedelutgifningen för hela unionen ej öfverstiga 500 mill. dollars. Finansministern skall tillse, att detta belopp blir fördeladt på de olika staterna i proportion till de inom staternas områden befintliga nationalbankernas kapitaltillgångar (aktiekapital + reserv-

1 Lagen är otydlig i afseende å den punkten, huruvida unionsobligationer få läggas som säkerhet för den extra sedelutgifningen.

2 Dessa villkor äro: att den utgifvande korporationen existerat $i$ Io år; att den $e_{j}$ under de senaste 1o åren brustit $\mathrm{i}$ betalning af kapital eller ränta å fonderad skuld, som den haft rätt att ikläda sig; att dess fonderade skulds nettobelopp ej öfverstiger to procent af taxeringsvärdet å den beskattningsbara egendomen inom dess område. 
fond). Skulle emellertid någon stats nationalbanker ej fullständigt utnyttja den sedelkontingent, som enligt denna fördelningsgrund skulle tillkomma dem, äger finansministern tilldela öfverskottet ăt nationalbanker $\mathrm{i}$ annan stat i samma del af unionen.

Äfven för denna extraordinära sedelutgifning gäller, att ett belopp i lagligt gällande mynt, motsvarande 5 procent af densamma, skall deponeras $\mathrm{i}$ unionskassan. Unionen har samma inlösningsskyldighet $\mathrm{i}$ afseende å dessa sedlar som i afseende å de på unionsobligationer grundade sedlarna.

För att förhindra, att denna extra sedelutgifning missbrukas, är den efter Tysklands föredöme underkastad en hög beskattning. Denna beskattning växer, i likhet med hvad fallet är i Norge, ju längre dylik sedelutgifning begagnas. För första månaden betalas en skatt, motsvarande 5 procents årlig ränta å medelbeloppet utelöpande sedlar. För hvarje följande månad ökas skatteprocenten med I procent, till dess Io procent uppnåtts, då stegringen afstannar. ${ }^{1}$ Den synpunkt, som dikterat denna bestämmelse, har äfven gjort, att den för den på unionsobligationer grundade sedelutgifningen gällande föreskriften, att bankerna ej få sammanlagdt indraga mer än 9 mill. dollars sedlar pr mănad, ej gäller för de nya sedlarna.

Rätten till denna extra sedelutgifning kan göras gällande antingen af hvarje särskild bank för sig eller ock genom förmedling af en på visst sätt organiserad förening af banker.

I förra fallet får sedelutgifningen endast grundas på räntebärande förbindelser, utgifna af stat eller kommun och af ofvan sid. 327 not 2 angifna beskaffenhet. I det senare fallet åter få äfven andra värdepapper, efter finansninisterns bepröfvande, användas, däribland äfven affärsväxlar och andra förbindelser, grundade på verkliga handelsaffärer, såvida de äro försedda med två namn och förfallotiden ej öfverstiger 4 månader. ${ }^{2}$ Men denna förmån är förenad med förpliktelser, hvilka för den framtida utvecklingen af Förenta Staternas bankväsende kan blifva af stor betydelse. Jag skall därför något närmare redogöra för dessa föreningar och de förpliktelser de medföra.

Ifrågavarande föreningar kallas för »national currency associations». För att en dylik förening skall kunna uppstå, fordras, att minst to banker, hvar och en med en reservfond af minst 20 procent af aktiekapitalet och hvilkas sammanlagda aktiekapital och reservfonder uppgå till minst 5 mill.

${ }^{1}$ Denna sedelutgifning är icke underkastad den skatt af $\mathrm{I}$, resp. ${ }^{1 / 2}$ procent, som betungar den på unionsobligationer grundade sedelutgifningen.

2 Dock får ingen bank utge sedlar, grủndade på deposition af »affärspapper», till högre belopp än 30 procent af summan af bankens aktiekapital och reservfond. 
dollars, ingå i densamma. Hvarje dylik förening tilldelas ett visst distrikt. Hvarje nationalbank inom distriktet, som har en reservfond af ofvannämnda storlek, äger, sedan finansministern gifvit sitt tillstånd, inträda i föreningen. Ingen nationalbank får sålunda vara medlem af flera dylika föreningar.

Dylik förenings styrelse skall bestå af en representant för hvarje bank. Bolagsordningen skall fastställas af finansministern.

Om nu en bank, tillhörande en dylik förening och för öfrigt kompetent till extra sedelutgifning, önskar erhålla rätt till sådan, har den att hos föreningen, men för unionens räkning, deponera de värdepapper, hvarpå den vill grunda sedelutgifningen. Föreningen pröfvar härefter värdepapperens godhet och gör, ifall de godkännas, anmälan hos myntkontrollören (comptroller of the currency) om tillstånd till dylik sedelutgifning för banken $i$ frăga. Myntkontrollören insänder ansökan med sitt utlåtande till finansministern, som enligt ofvan angifna grunder beslutar, om och till hvad belopp extra sedelutgifning må medges banken i fråga.

De $\mathrm{i}$ en sådan förening ingående bankerna äro, gent emot unionen och sålunda indirekt äfven i förhållande till allmänheten, solidariskt ansvariga för inlösningen af sedlar af här ifrågavarande slag, som någon af dem utgifvit, och, om unionskassan inlöst dylika sedlar, äger den för dylik fordran hos en medlem förmånsrätt $\mathrm{i}$ alla medlemmarnes tillgångar. På grund häraf har föreningen rätt att fordra af hvarje medlem, att han förstärker eller genom utbyte förbättrar de säkerheter, som deponerats hos föreningen såsom grundval för medlemmens extra sedelutgifning. Efterkommes ej dylik framställning, äger föreningen försälja de deponerade värdepapperen och insätta, hvad som influtit, i unionskassan till inlösen af de utelöpande sedlarne. Skulle därvid brist uppstå, har föreningen för bristen förmånsrätt i den ifrågavarande bankens tillgångar. Denna gemensamma ansvarighet har för ett visst fall utsträckts till den ordinarie, på unionsobligationer grundade sedelutgifningen. Såsom redan anförts skall hvarje nationalbank i unionskassan deponera i lagliga betalningsmedel ett belopp motsvarande 5 procent af såväl dess ordinarie som extraordinarie sedelutgifning. Om nu en $\mathrm{i}$ en dylik förening ingående bank underlåter att vidmakthålla denna kassadeposition vid föreskrifven höjd, skall föreningen anmanas att fylla bristen. Om föreningen ej efterkommer denna anmaning, äger unionskassan för inlösen af den ifrågavarande bankens sedlar af båda slagen använda de öfriga $\mathrm{i}$ föreningen ingående bankernas kassadepositioner, ${ }^{1}$ med skyl-

1 Denna anordning nödvändiggöres däraf, att unionskassan ej äger någon dispositionsrätt öfver de värdepapper, som ligga till grund för den extra sedelutgifningen af banker, till- 
dighet för dessa banker att fylla den brist i deras egna kassadepositioner, som härigenom tilläfventyrs uppkommit.

Dessa bestämmelser torde vara ägnade att främja sammanslutningen mellan bankerna och sålunda motväga verkan af förbudet för nationalbankerna att ha afdelningskontor. Den banksplittring, som härskar i Förenta Staterna, verkar, som erkändt är, mycket skadligt.

1908 ărs lag innehåller dessutom några andra bestämmelser af vikt. Som bekant är nationalbank skyldig att hafva en kassa, motsvarande viss procent af insättningarna i banken. Denna förpliktelse upphäfves $i$ regeln med afseende å depositioner af unionsmedel. ${ }^{1}$ Men å andra sidan skola nationalbankerna för deponerade unionsmedel erlägga ränta, hvars storlek finansministern bestämmer, men som ej får sättas lägre än till I procent.

\section{D.}

\section{Förenkling i postxäxelförfarandet.}

Nedanstående rader afse att fästa herrar bankmäns uppmärksamhet på det synnerligen opraktiska förfaringssätt, som i allmänhet föregår inlösta postväxlars öfversändande frăn en ort till en annan, vanligen frăn landsorten till bankcentrum, Stockholm, och att härutinnan åstadkomma en välbehöflig, rationell förändring.

Vid ofvannämnda remittering tillgår ju numera så, att en noggrann, detaljerad förteckning på remissans innehåll upprättas, innehăllande hvarje särskild växels utställare, utställningsort, nummer samt belopp, hvilket allt lägges till grund för kopior, som, för den händelse växlarne skulle förkomma, vore ett medel, hvarigenom duplettväxlar torde kunna anskaffas. Med tanke på den ringa möjlighet för att icke säga omöjlighet, att dylik remissa såsom »Rek.» verkligen skulle förkomma, torde det arbete, som sålunda nedlägges, stå $\mathrm{i}$ ett mycket oproportionerligt förhållande till dess verkliga värde. Tager man därtill $\mathrm{i}$ betraktande, att förteckningen $\mathrm{i}$ många fall kan vara felaktig, så ligger ju dessutom i det nu rădande systemet icke så liten risk.

hörande dylika föreningar, utan dispositionsrätten tillkommer föreningen. Genom den i texten angifna befogenheten kan unionskassan tvinga föreningen att realisera vederbörande banks värdepapper och deponera köpeskillingen $\mathrm{i}$ unionskassan för sedlarnas inlösen.

1 Jfr ang. denna punkt denna tidskrift årg. IX sid. 348 . 